九州大学学術情報リポジトリ

Kyushu University Institutional Repository

\title{
Study on an Evaporative Cooling Vest for Farm Workers
}

Maqsood, Aarish

Department of Agricultural Engineering, Bahauddin Zakariya University

Riaz, Mahmood

Department of Agricultural Engineering, Bahauddin Zakariya University

Muhammad H. Mahmood

Department of Agricultural Engineering, Bahauddin Zakariya University

Sultan, Muhammad

Department of Agricultural Engineering, Bahauddin Zakariya University

https://doi.org/10.5109/4102475

出版情報: Proceedings of International Exchange and Innovation Conference on Engineering \& Sciences (IEICES). 6, pp.116-121, 2020-10-22. Interdisciplinary Graduate School of Engineering Sciences, Kyushu University

バージョン：

権利関係 : 


\title{
Study on an Evaporative Cooling Vest for Farm Workers
}

\author{
Aarish Maqsood ${ }^{1}$, Mahmood Riaz ${ }^{1,2}$, Muhammad H. Mahmood ${ }^{1, *}$, Muhammad Sultan ${ }^{1}$ \\ ${ }^{1}$ Department of Agricultural Engineering, Bahauddin Zakariya University, Multan 60800, Pakistan \\ ${ }^{2}$ Agricultural Mechanization Research Institute (AMRI), Multan-Punjab, Pakistan \\ ${ }^{*}$ Corresponding author email: hamidmahmood@bzu.edu.pk
}

\begin{abstract}
The prolonged manifestation of workers working in warm and moist atmospheric conditions results in their decreased labour work productivity, excessive sweating, and heat stress. Flexible and comfortable cooling vests are an appropriate solution to enhance labour work productivity. The study aims to determine the cooling efficiency of the material. A model is developed work on the principle of indirect evaporative cooling (IDEC) provides cooled air without adding humidity i.e. latent heat of vaporization is transferred to working air, which makes more doable over the direct evaporative cooling (DEC). The performance of three different hygroscopic materials is evaluated on the base of the following parameters including ambient air temperature, primary and secondary air temperature, and relative humidity. This study shows that aspen pads have proven to be the most appropriate hygroscopic material in achieving a minimum temperature difference of $7^{\circ} \mathrm{C}$ at ambient temperature and relative humidity.
\end{abstract}

Keywords: Evaporative cooling; farm workers; thermal comfort; cooling vest

\section{INTRODUCTION}

Farmer workers are commonly subjected to severe heatrelated illnesses due to performing highly intense activities under prolonged exposure to hot and humid environments. Unawareness of broad variations in climate to farmers may have a great influence on their health thus leading to reduced work productivity [1] Pakistan is likely to be the utmost susceptible countries in Southeast Asia experience the extremely hot climatic conditions. Climatic constrain are prerequisites and fundamental conditions affecting their efficiency and work productivity. Unfortunately, farmers are the most affected community in developing countries due to the inefficient use of productivity and mechanized machines [2]. Environmental heat exhaustion is deemed one of the most health hazards that can increase their debility, coercing them to enhance the idle time and to reduce their work period, consequently losing their working capacity [3]. The majority of farmers facing a lot of difficulties regarding heat stress, subsequently resulting in a significant loss of working efficiency, misfunctioning of the central nervous system, heat cramps, heat illness and heat exhaustion [4]. Cited literature expose previous work of several authors struggling to increase labor work productivity such as preparation of evaporative cooling vest for enhanced labor activity in the hot environment [5], use of the material combination to provide a cool environment to labor for better agricultural activity [6-8], evaluating the effectiveness of cooling vest on workers working in open atmospheric conditions $[9,10]$. Several different techniques and procedures have been used in the past for developing an efficient cooling vest, the method for developing a cooling vest varies from material to material. The techniques used in past includes Fluid cooling garments (FCGs) [11], Phase change materials (PCMs) [6,12,13], and evaporative techniques [14,15]. The cooling technique should be selected based on ambient conditions (temperature, type of attire, work severity) along with operating conditions (cooling period, the weight of vest, mobility, and compactness) and type of system (area of cooling i.e. torso cooling) [16].
Personal cooling systems are widely used due to hot ambient conditions and applications includes surgeons [17], aerospace and spacesuits [18], chemical warfare conditions [19], industrial environment, astronauts [20], firefighting [21], etc.

FCGs include heat removal employing circulating fluid that acts as a cooling agent hence provide thermal comfort [22]. Circulating fluid moves in the tubes around the torso drive through a mechanical pump by utilizing battery for ensured operation. FCGs provides better cooling efficiency, reliability, and cooling adjustment and capacity in comparison to other cooling techniques. In contrast, increase weight due to heavy components i.e. battery, water storage tank restricts the mobile work and increases the body metabolism hence diminishes the efficiency. On the other hand, PCM comprises anyone of ice, salt, a mixture of sand silt and clay, metallic, and paraffin which releases and absorbs moisture at the desired rate [14]. It can absorb or release heat during the melting of material with a small temperature span. PCM is used in a variety of application includes building structure to regulate the temperature, space industry [23], electronic industry [24], solar cooling and solar power plants [25], solar dryers in the agricultural industry [26], photovoltaic electricity systems [27], preservation of food and pharmaceutical products [28], surgeon comfort [17], waste heat recovery systems [29] and domestic hot water [30]. etc. PCMs have a low working duration and required refrigeration for solidifying to reuse the materials, henceforth reducing the working efficiency. Comparative evaluation of PCM and FCGs reveals PCM as more effective and efficient. Besides they don't require energy for operation [5].

Solid-state cooling is another technique that is frequently used for cooling, based on caloric effect (electro, magneto, baro and elasto) of several materials. Caloric effect is responsible for the change in temperature of specific material depending on actual environmental conditions and thermal conditions which are desired. [31] Electrocaloric effect produces by the variation in the electric field. When electric field is applied or removed, 
its entropy decreases or increases depends upon the organizing and disorder of the inner structure of the material. The electrocaloric prototypes can produce the promising $20 \mathrm{~K}$ as the most elevated temperature range estimated by [32] and for magnetocaloric prototypes can produce cooling power up to $3042 \mathrm{~W}$ or temperature span as large as about $40 \mathrm{~K}$ measured by [33].
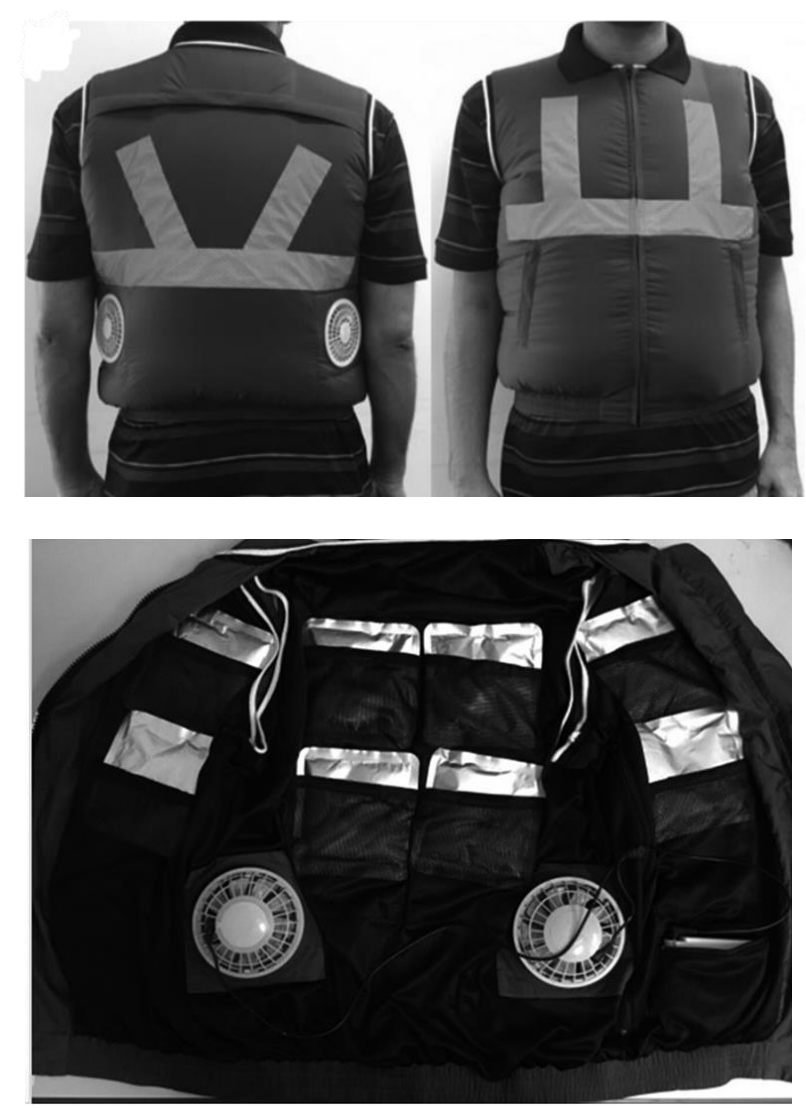

Fig. 1. Cooling vest based on cooling pads and ventilation fans [10].

Evaporative cooling techniques works on the principle of evaporation of water and heat is transferred from air to water in the form of latent energy, subsequently, the temperature of air cools down. It does not need any power source or energy to provide the desired cooling capacity like fluid cooling and phase change cooling. They can depend on water that is provided manually or sweat produced by the human body. The applications of evaporative cooling includes industrial building [34,35], power plant [36], agriculture storage applications [37] livestock thermal comfort [38], domestic air conditioning $[39,40]$ and green housing air conditions [41].

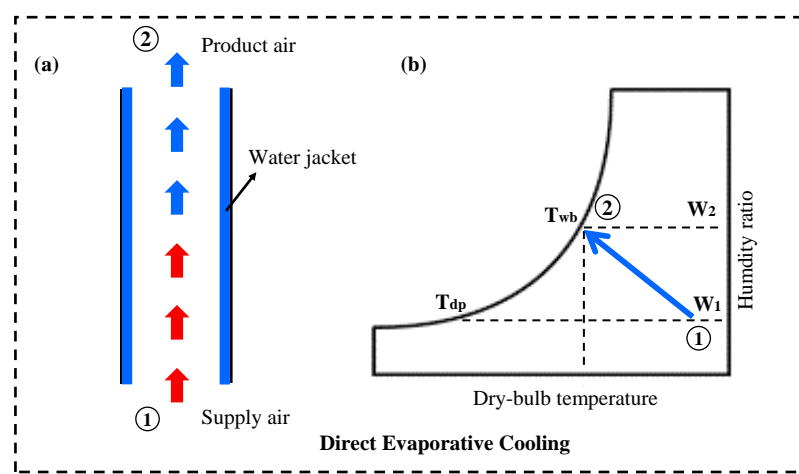

Fig. 2 A typical direct evaporative cooling technique (a) schematic diagram (b) psychometric representation of

DEC technique (reproduced from [46]).
Its limitation is that it is highly dependent on ambient environment temperature, the discrepancy between dry bulb temperature and wet bulb temperature, consumption of water, and cooling efficiency during humid regions [42]. Evaporative cooling techniques are mainly applied to torso areas of the human body [43-45]. The weight of the evaporative cooling garment reached up to $1.5-2 \mathrm{~kg}$ and its cost because of fans and fabric [5].

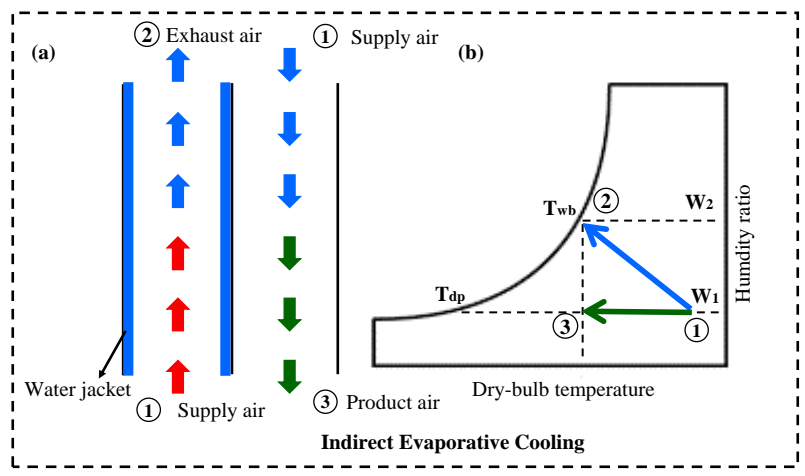

Fig. 3 A typical indirect evaporative cooling technique

(a) schematic diagram (b) psychometric representation of IDEC technique (reproduced from [46]).

The basic principle and features of the direct evaporative cooling technique can be explained in Error! Reference source not found.(a) and (b) representing the schematic and psychometric diagram of direct evaporative cooling technique.

The indirect evaporative cooling technique comprises two passages i.e. dry and wet channel. The wet channel is used to cool the product air in a dry channel and produces air at a constant humidity ratio which makes it exceptional and more effective. It saves energy and cost and provides cool air at constant absolute humidity [15]. It usually employs a wet surface and dry stream of air in separate sections by the cool wet sheet as its heat exchanger. The basic principle and features of the indirect evaporative cooling technique can be described from Fig. 3(a) and (b) demonstrating the schematic and psychometric diagram of direct evaporative cooling technique.

This study aims to develop a lab scale model to study the effectiveness of locally available materials. The IDEC technique is used for the model. Temperature of inlet and outlet of primary and secondary are measured to estimate the effectiveness of material.

\section{METHODOLOGY}

The study was conducted in the Department of Agricultural Engineering, Bahauddin Zakariya University, Multan $\left(30.26^{\circ} \mathrm{N}, 71.51^{\circ} \mathrm{E}\right)$. The tests were performed in November last year. In the preparation of vests, a verity of hygroscopic materials can be used. Selected materials are cotton, felt, and aspen. Selection of materials based on adsorption capacity of materials. The proposed model is used to evaluate the cooling efficiency of prescribed materials. In the fabrication of IDEC model acrylic plastic, aluminum tube, fans, cotton, felt and aspen pads are used as shown in Fig. 4. From the experimental setup, only product air temperature data has been collected to evaluate the cooling efficiency of the material. Humidity ratio, vapor pressure, and cooling efficiency can be calculated by using the given relationships: 


$$
\begin{gathered}
p_{v}=p_{w}-\left[\frac{\left(p_{b}-p_{w}\right)\left(t_{d}-t_{w}\right)}{1533-1.44 t_{w}}\right] \\
W=\frac{0.622 p_{v}}{p_{b}-p_{v}} \\
E=\frac{T_{a}-T_{e}}{T_{a}-t_{w}} \times 100
\end{gathered}
$$

Where $p_{v}, p_{w}$ and $p_{b}$ represents the vapour pressure at dry bulb temperature, vapour pressure at wet bulb temperature, barometric pressure and $\mathrm{W}, \mathrm{T}_{\mathrm{e}}$, and $\mathrm{E}$ represent the humidity ratio, product air temperature and cooling efficiency, respectively.

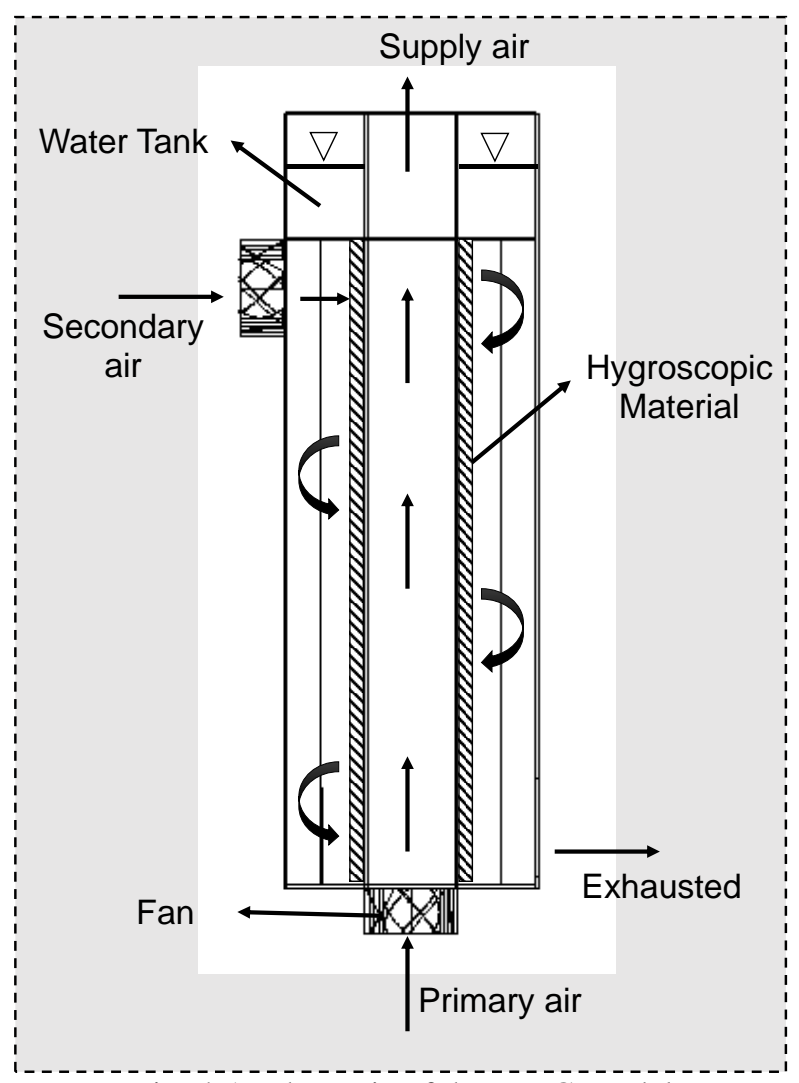

Fig. 4 A schematic of the IDEC Model.

The proposed model is composed of four major parts: the insulating wall, the hygroscopic material, the water tank, and the primary air channel. The exterior of the model is rendered with acrylic plastic to establish a barrier between the ambient air and the product air within the prototype. The center layer is made of moisture-wicking texture, the primary objective behind which is to build the evaporation rate by reaching the air. The air is allowed to move around the hygroscopic material that allows the heat and mass exchange between air and moisture and it is wrapped on the aluminum tube. The cooling effect depends upon the latent heat of vaporization and temperature difference between water and air. Water evaporates as it absorbs the heat from the air. It causes to increase in humidity while decreasing the temperature of the air. Consequently, the temperature of the aluminum tube is cooled down. There are three hygroscopic materials used in this test. Cotton felt and aspen pads. The water tank of the model is used to drop water under gravity through the orifice, which directly falls on the hygroscopic material. The primary air channel is used to mass and heat transfer between air and aluminum tube and the air is allowed to pass through it.

\section{RESULT AND DISCUSSION}

The proposed model is based on the IDEC technique which is usually invested by ambient conditions, mainly the difference of wet bulb temperature and dry bulb temperature. The inlet air temperature and $\mathrm{RH}$ to a single channel or dry channel are $25^{\circ} \mathrm{C}$ and $65 \% \mathrm{RH}$.

Table 1. shows the temperature difference between the primary air channel and the secondary air channel. And Table 2 . shows the humidity ratio difference between the primary air channel and the secondary air channel. The air comes from the primary channel is at low temperature and the same humidity ratio because only heat flow occurs between air and aluminum tube. The air comes from the secondary air channel is at high humidity ratio, high relative humidity, and low temperature.

Table 1 . The temperature difference between primary and secondary channel

\begin{tabular}{llll}
\hline \hline Materials & $\begin{array}{l}\text { Inlet } \\
\text { temp. }\end{array}$ & $\begin{array}{l}\text { Primary air } \\
\text { outlet temp. }\end{array}$ & $\begin{array}{l}\text { Secondary air } \\
\text { outlet temp. }\end{array}$ \\
\hline Cotton & $25^{\circ} \mathrm{C}$ & $23.5^{\circ} \mathrm{C}$ & $21^{\circ} \mathrm{C}$ \\
Felt & $25^{\circ} \mathrm{C}$ & $24^{\circ} \mathrm{C}$ & $21.5^{\circ} \mathrm{C}$ \\
$\begin{array}{l}\text { Aspen } \\
\text { pads }\end{array}$ & $25^{\circ} \mathrm{C}$ & $22^{\circ} \mathrm{C}$ & $20^{\circ} \mathrm{C}$ \\
\hline \hline
\end{tabular}

Table 2. Relative humidity difference between primary and secondary channel

\begin{tabular}{llll}
\hline \hline Materials & $\begin{array}{l}\text { Inlet } \\
\text { humidity }\end{array}$ & $\begin{array}{l}\text { Primary } \\
\text { outlet } \\
\text { humidity }\end{array}$ & $\begin{array}{l}\text { Secondary air } \\
\text { outlet } \\
\text { humidity }\end{array}$ \\
\hline Cotton & $65 \%$ & $66 \%$ & $75 \%$ \\
Felt & $65 \%$ & $68 \%$ & $77 \%$ \\
$\begin{array}{l}\text { Aspen } \\
\text { pads }\end{array}$ & $65 \%$ & $70 \%$ & $81 \%$ \\
\hline \hline
\end{tabular}

Fig. 5 illustrates the temperature variation among various materials under the IDEC prototype model at ambient temperature. It has been found that the minimum reduction of the temperature of the aspen pad is $22^{\circ} \mathrm{C}$ without added humidity. Aspen pad shows the best hygroscopic material with a cooling efficiency of $63.8 \%$ while the humidity ratio remains the same in all materials is $12.4 \mathrm{~g}$ of moisture $/ \mathrm{kg}$ of dry air.

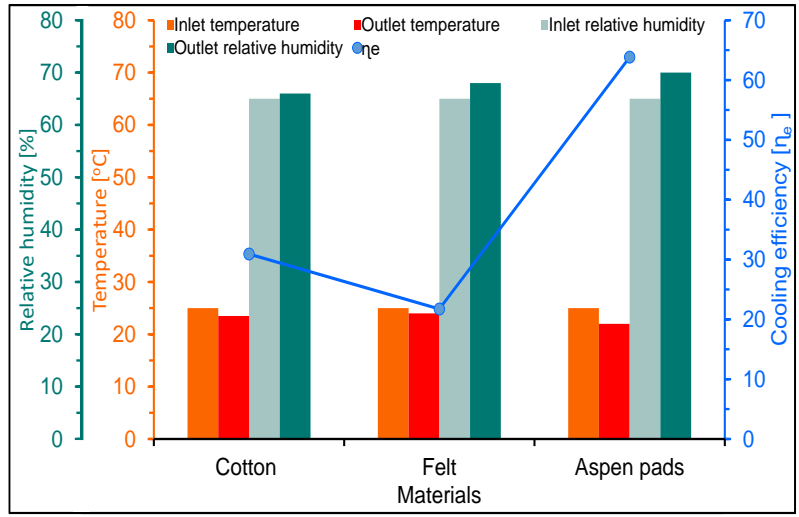


Fig. 5 Performance comparison of different materials.

\section{CONCLUSION}

The focus of this study is to find such kind material and vest which has less weight, compactness, and economical to farm worker. Aspen pad is the best with a cooling efficiency of $63.8 \%$. The test was conducted in the winter season, in which temperature is low and relative humidity is high. That's why results are not much effective. The limitation is that it is effective only in hot and dry conditions. It is expected to temperature difference would reach $7^{\circ} \mathrm{C}$ in hot ambient conditions.

\section{REFERENCES}

[1] Singh S, Ahlawat S, Sanwal S. Effect of Heat Stress on Farm Workers - A Review. Int J Curr Microbiol Appl Sci 2018;7:2397-401. https://doi.org/10.20546/ijcmas.2018.710.278.

[2] Fahad S, Wang J. Climate change, vulnerability, and its impacts in rural Pakistan: a review.

Environ Sci Pollut Res 2020;27:1334-8. https://doi.org/10.1007/s11356-019-06878-1.

[3] Frimpong K, Eddie Van Etten EJ, Oosthuzien J, Fannam Nunfam V. Heat exposure on farmers in northeast Ghana. Int J Biometeorol 2017;61:397-406. https://doi.org/10.1007/s00484-016-1219-7.

[4] Miller VS, Bates GP. The thermal work limit is a simple reliable heat index for the protection of workers in thermally stressful environments. Ann Occup Hyg 2007;51:553-61. https://doi.org/10.1093/annhyg/mem035.

[5] Raad R, Itani M, Ghaddar N, Ghali K. A novel M-cycle evaporative cooling vest for enhanced comfort of active human in hot environment. Int J Therm Sci 2019;142:1-13. https://doi.org/10.1016/j.ijthermalsci.2019.04.01 0 .

[6] Itani M, Ghaddar N, Ghali K, Ouahrani D, Chakroun W. Cooling vest with optimized PCM arrangement targeting torso sensitive areas that trigger comfort when cooled for improving human comfort in hot conditions. Energy Build 2017;139:417-25.

https://doi.org/10.1016/j.enbuild.2017.01.036.

[7] Itani M, Ouahrani D, Ghaddar N, Ghali K, Chakroun W. The effect of PCM placement on torso cooling vest for an active human in hot environment. Build Environ 2016;107:29-42. https://doi.org/10.1016/j.buildenv.2016.07.018.

[8] Hamdan H, Ghaddar N, Ouahrani D, Ghali K, Itani M. PCM cooling vest for improving thermal comfort in hot environment. Int $\mathrm{J}$ Therm Sci 2016;102:154-67. https://doi.org/10.1016/j.ijthermalsci.2015.12.00 1.

[9] Zhao Y, Yi W, Albert P, Chan C, Wong FKW, Yam MCH. Evaluating the Physiological and Perceptual Responses of Wearing a Newly Designed Cooling Vest for Construction Workers 2017:1-19. https://doi.org/10.1093/annweh/wxx055.

[10] Yi W, Zhao Y, Albert P, Chan C. Evaluating the Effectiveness of Cooling Vest in a Hot and Humid Environment 2018;61:481-94. https://doi.org/10.1093/annweh/wxx007.

[11] Bartkowiak G, Dąbrowska A, Włodarczyk B. Construction of a garment for an integrated liquid cooling system. Text Res J 2015;85:1809-16. https://doi.org/10.1177/0040517515576324.

[12] Akeiber H, Nejat P, Majid MZA, Wahid MA, Jomehzadeh F, Zeynali Famileh I, et al. A review on phase change material (PCM) for sustainable passive cooling in building envelopes. Renew Sustain Energy Rev 2016;60:1470-97. https://doi.org/https://doi.org/10.1016/j.rser.201 6.03.036.

[13] Ouahrani D, Itani M, Ghaddar N, Ghali K, Khater B. Experimental study on using PCMs of different melting temperatures in one cooling vest to reduce its weight and improve comfort. Energy Build 2017;155:533-45. https://doi.org/10.1016/j.enbuild.2017.09.057.

[14] Yang Y, Stapleton J, Diagne BT, Kenny GP, Lan CQ. Man-portable personal cooling garment based on vacuum desiccant cooling. Appl Therm Eng 2012;47:18-24. https://doi.org/10.1016/j.applthermaleng.2012.0 4.012 .

[15] Heidarinejad G, Moshari S. Novel modeling of an indirect evaporative cooling system with cross-flow configuration. Energy Build 2015;92:351-62. https://doi.org/10.1016/j.enbuild.2015.01.034.

[16] Nunneley SA. Water cooled garments: A review. Space Life Sci 1970;2:335-60. https://doi.org/10.1007/BF00929293.

[17] Lang $\varnothing$ T, Nesbakken R, Færevik H, Holbø K, Reitan J, Yavuz Y, et al. Cooling vest for improving surgeons' thermal comfort: A multidisciplinary design project. Minim Invasive Ther Allied Technol 2009;18:20-9. https://doi.org/10.1080/13645700802649383.

[18] Guo T, Shang B, Duan B, Luo X. Design and testing of a liquid cooled garment for hot environments. J Therm Biol 2015;49-50:47-54. https://doi.org/10.1016/j.jtherbio.2015.01.003.

[19] Shapiro Y, Pandolf KB, Sawka MN, Toner MM, Winsmann FR, Goldman RF. Auxiliary cooling: Comparison of air-cooled vs. watercooled vests in hot-dry and hot-wet environments. Aviat Sp Environ Med 1982;53:785-9.

[20] Webbon B, Williams B, Kirk P, Elkins W, Stein R. A Portable Personal Cooling System for Mine Rescue Operations. J Manuf Sci Eng Trans ASME 1978;100:53-9. https://doi.org/10.1115/1.3439346.

[21] Bennett BL, Hagan RD, Huey KA, Minson C, Cain D. Comparison of two cool vests on heatstrain reduction while wearing a firefighting ensemble. Eur J Appl Physiol Occup Physiol 1995;70:322-8. https://doi.org/10.1007/BF00865029.

[22] Wang T, Wang L, Bai L, Lin G, Bu X, Liu X, et al. Experimental study on the performance of a liquid cooling garment with the application of MEPCMS. Energy Convers Manag 
2015;103:943-57.

https://doi.org/10.1016/j.enconman.2015.07.043

[23] Zhou Z, Zhang Z, Zuo J, Huang K, Zhang L.

Phase change materials for solar thermal energy storage in residential buildings in cold climate. Renew Sustain Energy Rev 2015;48:692-703. https://doi.org/https://doi.org/10.1016/j.rser.201 5.04 .048 .

[24] Dhaidan NS, Khodadadi JM. Melting and convection of phase change materials in different shape containers: A review. Renew Sustain Energy Rev 2015;43:449-77. https://doi.org/https://doi.org/10.1016/j.rser.201 4.11.017.

[25] Aydin D, Casey SP, Riffat S. The latest advancements on thermochemical heat storage systems. Renew Sustain Energy Rev 2015;41:356-67. https://doi.org/https://doi.org/10.1016/j.rser.201 4.08.054

[26] Shalaby SM, Bek MA, El-Sebaii AA. Solar dryers with PCM as energy storage medium: A review. Renew Sustain Energy Rev 2014;33:110-6. https://doi.org/https://doi.org/10.1016/j.rser.201 4.01.073.

[27] Ma T, Yang H, Zhang Y, Lu L, Wang X. Using phase change materials in photovoltaic systems for thermal regulation and electrical efficiency improvement: A review and outlook. Renew Sustain Energy Rev 2015;43:1273-84. https://doi.org/https://doi.org/10.1016/j.rser.201 4.12.003

[28] Belman-Flores JM, Barroso-Maldonado JM, Rodríguez-Muñoz AP, Camacho-Vázquez G. Enhancements in domestic refrigeration, approaching a sustainable refrigerator - A review. Renew Sustain Energy Rev 2015;51:955-68.

https://doi.org/https://doi.org/10.1016/j.rser.201 5.07.003

[29] Fang G, Tang F, Cao L. Preparation, thermal properties and applications of shape-stabilized thermal energy storage materials. Renew Sustain Energy Rev 2014;40:237-59. https://doi.org/https://doi.org/10.1016/j.rser.201 4.07.179.

[30] Seddegh S, Wang X, Henderson AD, Xing Z. Solar domestic hot water systems using latent heat energy storage medium: A review. Renew Sustain Energy Rev 2015;49:517-33. https://doi.org/https://doi.org/10.1016/j.rser.201 5.04.147

[31] Greco A, Aprea C, Maiorino A, Masselli C. A review of the state of the art of solid-state caloric cooling processes at room-temperature before 2019. Int J Refrig 2019;106:66-88. https://doi.org/10.1016/j.ijrefrig.2019.06.034.

[32] Engelbrecht K, Tušek J, Eriksen D, Lei T, Lee $\mathrm{CY}$, Tušek J, et al. A regenerative elastocaloric device: Experimental results. J Phys D Appl Phys 2017;50. https://doi.org/10.1088/13616463/aa8656.

[33] Jacobs S, Auringer J, Boeder A, Chell J,
Komorowski L, Leonard J, et al. The performance of a large-scale rotary magnetic refrigerator. Int. J. Refrig., vol. 37, 2014, p. 8491. https://doi.org/10.1016/j.ijrefrig.2013.09.025.

[34] da Veiga AP, Güths S, da Silva AK.

Evaporative cooling in building roofs: Local parametric and global analyses (Part-2). Sol Energy 2020;207:1009-20. https://doi.org/https://doi.org/10.1016/j.solener. 2020.05.091.

[35] Miyazaki T, Akisawa A, Nikai I. The cooling performance of a building integrated evaporative cooling system driven by solar energy. Energy Build 2011;43:2211-8. https://doi.org/10.1016/j.enbuild.2011.05.004.

[36] Tang L, Sun D, Pan J. Application of Evaporative Cooling Ventilation technology to Turbine House of one power plant in Pakistan. Procedia Eng 2017;205:902-7. https://doi.org/https://doi.org/10.1016/j.proeng.2 017.10.105.

[37] Mahmood MH, Sultan M, Miyazaki T, Koyama S. Desiccant Air-Conditioning System for Storage of Fruits and Vegetables : Pakistan Preview 2016. https://doi.org/10.5109/1657381.

[38] Raza HMU, Sultan M, Bahrami M, Khan AA. Experimental investigation of evaporative cooling systems for agricultural storage and livestock air-conditioning in Pakistan 2019.

[39] Joudi KA, Mehdi SM. Application of indirect evaporative cooling to variable domestic cooling load. Energy Convers Manag 2000;41:1931-51. https://doi.org/10.1016/S0196-8904(00)000042.

[40] Davis MJM, Ramírez F, Vallejo AL. Vertical Gardens as Swamp Coolers. Procedia Eng 2015;118:145-59. https://doi.org/https://doi.org/10.1016/j.proeng.2 015.08.413.

[41] Ma Z, Ren H, Lin W. A review of heating, ventilation and air conditioning technologies and innovations used in solar-powered net zero energy Solar Decathlon houses. J Clean Prod 2019;240:118158. https://doi.org/https://doi.org/10.1016/j.jclepro.2 019.118158.

[42] Peng J, Li L, Liu F, Chen S. Application on Evaporative Cool Technique in Garment Workshop in Hot-humid Area. Procedia Eng 2015;121:2029-36. https://doi.org/10.1016/j.proeng.2015.09.203.

[43] Xu X, Gonzalez J. Determination of the cooling capacity for body ventilation system. Eur J Appl Physiol 2011;111:3155-60. https://doi.org/10.1007/s00421-011-1941-0.

[44] Sun YW, Guo DM, Jia ZY. An automatic modelling strategy for the reverse engineering of wrap-around freeform surfaces. Int J Mater Prod Technol 2008;33:50-64. https://doi.org/10.1504/IJMPT.2008.019772.

[45] Chinevere TD, Cadarette BS, Goodman DA, Ely BR, Cheuvront SN, Sawka MN. Efficacy of body ventilation system for reducing strain in 
Proceeding of International Exchange and Innovation Conference on Engineering \& Sciences (IEICES) 6 (2020)

warm and hot climates. Eur J Appl Physiol

2008;103:307-14.

https://doi.org/10.1007/s00421-008-0707-9.

[46] Mahmood MH, Sultan M, Miyazaki T, Koyama

S, Maisotsenko VS. Overview of the

Maisotsenko cycle - A way towards dew point

evaporative cooling. Renew Sustain Energy Rev

2016;66:537-55.

https://doi.org/10.1016/j.rser.2016.08.022. 